\title{
Proposal for the nomination of Lower Globigerina Limestone of the Maltese Islands as a "Global Heritage Stone Resource"
}

\author{
${ }^{1}$ Department of Conservation and Built Heritage, Faculty for the Built Environment, University of Malta, Msida MSD 2080, Malta; \\ *Corresponding author,E-mail: joann.cassar@um.edu.mt \\ ${ }^{2}$ Department of Architecture and Urban Design, Faculty for the Built Environment, University of Malta, Msida MSD 2080, Malta \\ ${ }^{3}$ Department of Geosciences, Faculty of Science, University of Malta, Msida MSD 2080, Malta
}

(Received: June 21, 2016; Revised accepted: November 29, 2016)

http://dx.doi.org/10.18814/epiiugs/2017/v40i3/017025

The Lower Globigerina Limestone of the Maltese Islands is here being proposed for nomination as a "Global Heritage Stone Resource". This stone, continuously used for building and sculpture for 6000 years, is well suited to fit this global designation as it is not only of great local cultural, historic and economic importance, but it is also the building stone used in construction of the UNESCO, and hence internationally recognized, World Heritage city of Valletta, as well as the UNESCO-listed Prehistoric Megalithic Temples of the Maltese Islands. The stone was also exported to several European and North African countries especially in the early $20^{\text {th }}$ century. The entire range of archaeological remains and historic architecture which cover the Maltese Islands have been built in this stone, and encompass innumerable palaces and churches, including the fortified cities of Valletta, Mdina (the old capital of Malta), the Three Cities on the Grand Harbour and the Citadel of Gozo, as well as the vernacular architecture ubiquitous within the village cores all over the Islands. The soft limestone has also been widely used over the millennia for elaborate and extensive sculptural motifs. Practically the only natural resource of the Islands, it continues to be quarried today, and is used not only for new construction, but also for the regular restoration of Malta's great and imposing architectural heritage, remaining thus an important pillar of the Maltese economy.

\section{Introduction}

This paper is aimed at proposing Lower Globigerina Limestone, extracted in the Maltese Islands, for nomination as a "Global Heritage Stone Resource" (GHSR). This stone has also been called "Malta stone" in the past, and is currently referred to, in the construction industry, as "franka" (meaning "freestone"), or "softstone". The stone will be defined according to its geological setting and characteristics, historical and cultural importance over the millennia, as well as its significance as an economic resource, which it continues to be today.
These will cover the nomination criteria that have been established by the Board of Management of the Heritage Stone Task Group (HSTG), as specified in the Task Group's checklist for "Global Heritage Stone Resource" designation (revised October 2014), and as reported on the Global Heritage Stone website www.globalheritagestone.com.

\section{Criteria for GHSR Recognition}

Criteria for designating a Global Heritage Stone Resource (GHSR) have been developed by the Heritage Stone Task Group (HSTG) of IUGS and Commission C-10 of IAEG (Cooper, 2014). The Heritage Stone Task Group checklist states that a natural stone can be recognised as a GHSR if most of the following attributes are covered:

a) historic use for a significant period (at least 50 years);

b) wide-ranging geographic application;

c) utilisation in significant public or industrial projects;

d) common recognition as a cultural icon;

e) ongoing quarrying and availability; and

f) providing potential benefits (cultural, scientific, environmental and/or commercial) (Marker, 2014).

Thus, for a stone to be nominated it must have been widely used over a long period of time, needs to have acquired cultural and historical significance by being used in significant buildings or sculpture, and be still quarried. The case will be made here that, for the Lower Globigerina Limestone of the Maltese Islands, all of these criteria are fulfilled. In the case of wide geographical use, which is also a desirable criterion, this is not an essential GHSR characteristic (Hughes et al., 2013). The paper will nonetheless discuss how international recognition of the stone has been achieved, by having significant buildings in Malta recognised as UNESCO World Heritage, including the entire capital city of Valletta, wholly built of this limestone, as well as what are classified as amongst the oldest free-standing structures in the world, the Maltese Prehistoric Temples (http://whc.unesco.org/en/ statesparties/MT/). In addition, this stone is still being extracted from a number of quarries in the Maltese Islands, and, in being one of the very few mineral resources on the Islands, is a significant asset to the local economy.

It is on the basis of these criteria, which will be further discussed 
below, that the Lower Globigerina Limestone is being proposed for nomination as a GHSR by a working group (authors) within the University of Malta, where research on the stone has been conducted for the last 30 years; this research covers geochemical, mineralogical and petrographical studies, as well as the determination of physical and mechanical properties (Bianchi, 1975; Cachia, 1985; Bonello, 1988; Zammit, 1989; Saliba, 1990; Farrugia, 1991; Sammut, 1991; Xuereb, 1991; Cassar, 2002, 2004, 2010; Cassar and Vella, 2003; Rothert et al., 2007; Cassar et al., 2008; Diana et al., 2014; Zammit and Cassar, 2017) - data given in Table 1 (below). This paper will also be utilised as the main vehicle to provide the data as required by the Checklist for "Global Heritage Stone Resource" Designation (revised October 2014).

\section{The Stone and Its Context}

The Maltese Islands consist of three main islands (Fig. 1), covering approximately $316 \mathrm{~km}^{2}$ of exposed land, lying $93 \mathrm{~km}$ due south of the Ragusa Peninsula of Sicily on the southern end of the Pelagian shelf. The Islands are made up of sedimentary rocks, ranging from pure carbonates to marly-carbonates, formed in marine water depths of up to $200 \mathrm{~m}$ on a stable near-horizontal platform (Pedley et al., 1976). The Maltese sedimentary sequence consists of five formations - (from oldest to youngest) Lower Coralline Limestone, Globigerina Limestone, Blue Clay, Greensand, Upper Coralline Limestone (Fig. 2) - covering the Oligocene (Paleogene period) and Miocene epochs (Neogene period) (Pedley, 1978). The outcropping succession also includes sporadic Quaternary deposits.

The Globigerina Limestone Formation forms part of the OligoMiocene 'soft limestones' found widely in the Mediterranean Basin, including Turkey, Israel, Tunisia, Spain and Italy. It is the most widely distributed formation on the Maltese Islands, and consists of a yellow to greyish, medium to fine grained wackestone-packstone dominated

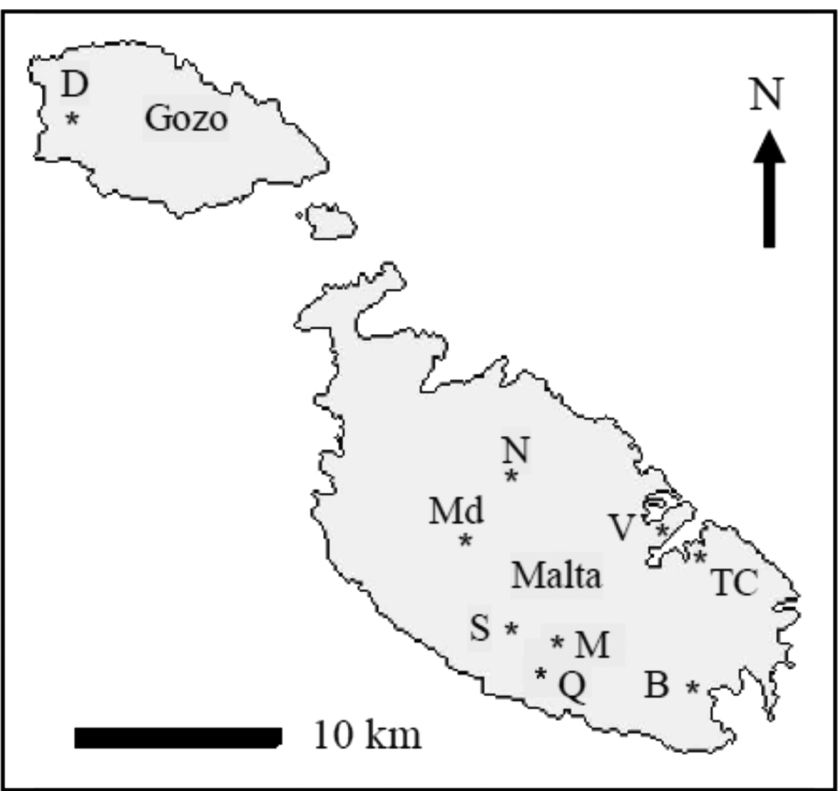

Figure 1. Map of the Maltese Islands showing main urban and quarry areas. Key: $D=$ Dwejra (San Lawrenz), $N=$ Naxxar, $M d=$ Mdina, $S=$ Siggiewi, $M=$ Mqabba, $Q=$ Qrendi, $B=$ Birzebbuga, $V=$ Valletta, TC $=$ Three Cities (Cottonera).

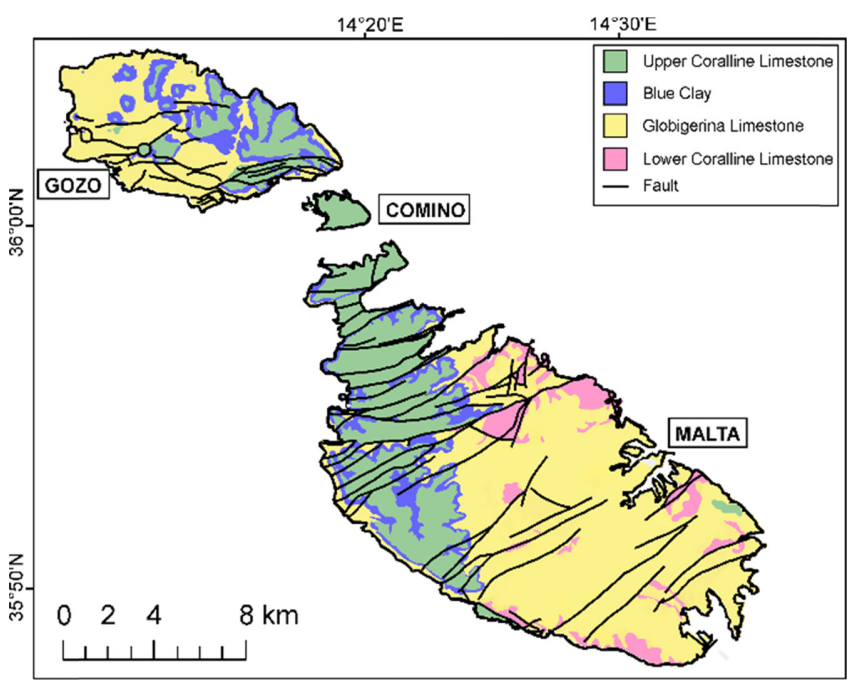

Figure 2. Geological map of the Maltese Islands, showing the five main sedimentary formations, including the Globigerina Limestone Formation, which is the source of the stone being proposed for nomination as a GHSR (Source: Oil Exploration Directorate, 1993).

by planktonic foraminiferid tests (Baldassini and Di Stefano, 2017). The formation is massive, poorly to moderately consolidated, and intensely burrowed. The Globigerina Limestone Formation was deposited in outer shelf environments between the Late Chattian and Langhian, and is up to $200 \mathrm{~m}$ thick (Pedley et al., 1976).

The Globigerina Limestone Formation is made up of three members, called the Lower Globigerina Limestone, Middle Globigerina Limestone and Upper Globigerina Limestone, separated from each other by two phosphatic hardgrounds (named C1 and C2) (Pedley et al., 1976). It is Lower Globigerina Limestone, the oldest member of the Globigerina Limestone Formation, which has been used as the main local building material for millennia (Fig. 3). The thickness of the Lower Globigerina Limestone member varies from $>100 \mathrm{~m}$ in the Valletta Basin, to $<5 \mathrm{~m}$ along western Malta (Pedley et al., 1976). Lower Globigerina Limestone (Fig. 4) comprises planktonic foraminiferal biomicrites, biomicrosparites, wackestones and packstones

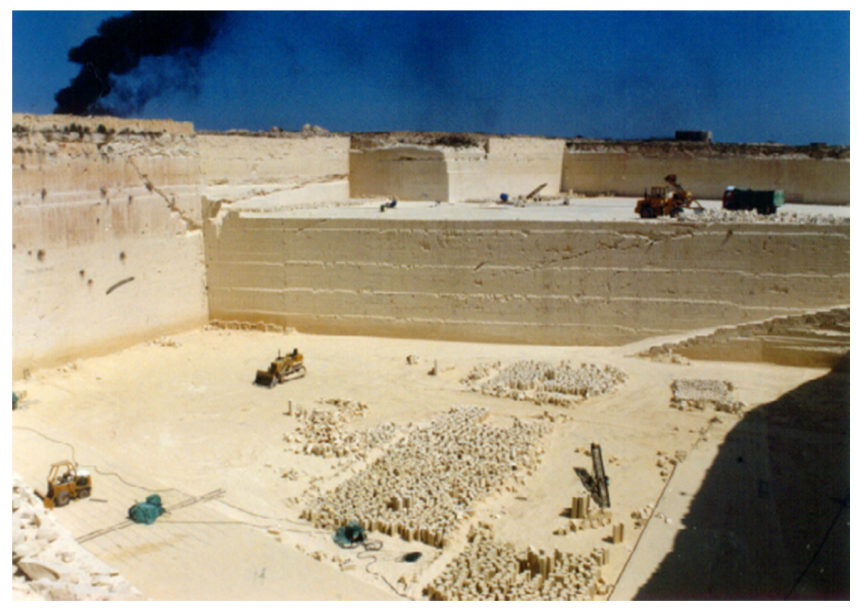

Figure 3. Open pit quarry extraction in the quarry area of Mqabba, Malta. Extraction is by automated sawing machines. Processing starts in the quarry and continues on site. 


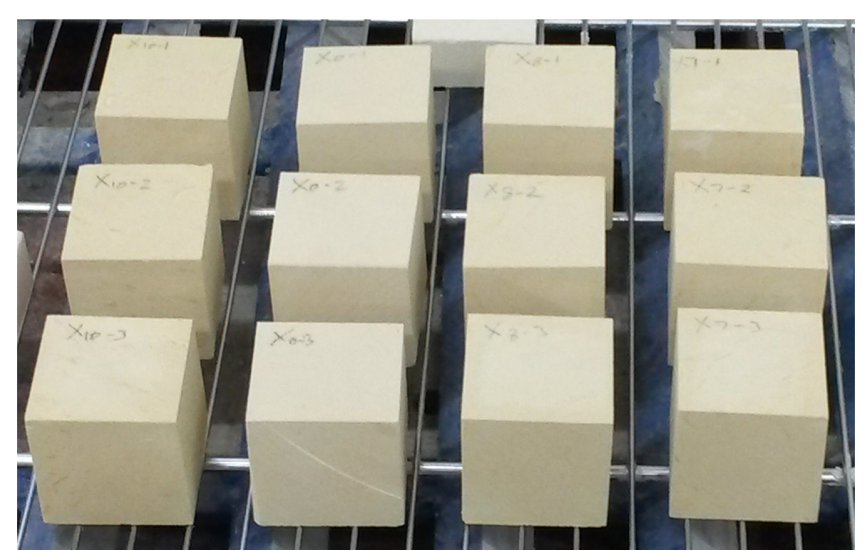

Figure 4. Close surface view of sawn cubes of Globigerina Limestone, showing fine, smooth and homogeneous texture, but some colour variations. The size of each cube is $5 \times 5 \times 5 \mathrm{~cm}$.

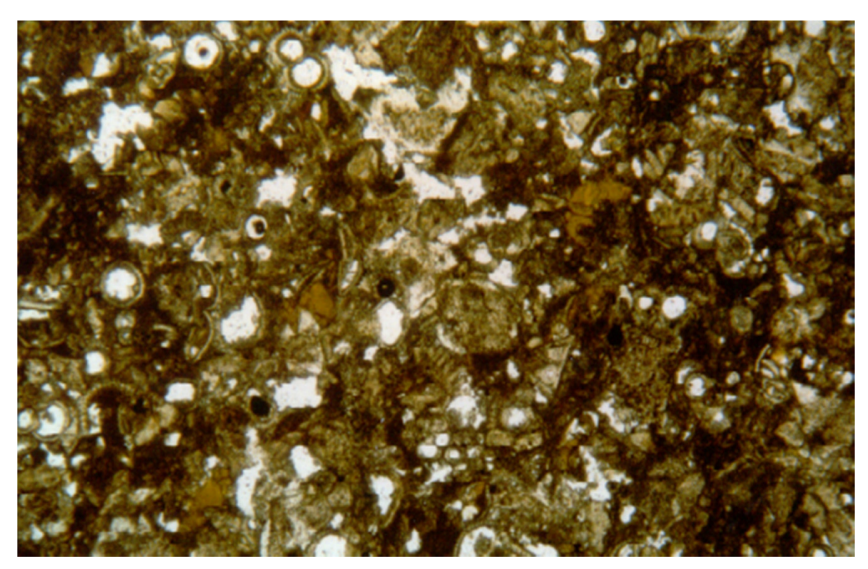

Figure 5. Optical microphotograph of Globigerina Limestone showing fine texture, foraminifera, micritic matrix and inter-and intra-granular porosity. Crossed nicols, $\times 2.5$.

dominated by globigerinid tests (Fig. 5), which are pale yellow, massively bedded and medium to fine grained (Pedley et al., 1976; Baldassini and Di Stefano, 2017). Most of the original bedding of the member has been destroyed by intense bioturbation. This is particularly the case in the deeper section of the Lower Globigerina Limestone member, where anomalously dense and large bioturbation gives rise to the "soll" layer - a very fine cream to yellow bedded limestone that weathers rapidly and unevenly. Lower Globigerina Limestone is comprised of calcite ( $>92 \%$ ) as well as small amounts of quartz, feldspar, apatite, glauconite and clay minerals. Detailed composition data have been published in Cassar (2004). The total porosity is very high, reaching values of up to $41.4 \%$ (Cassar and Vannucci, 2001). Further geotechnical and petrophysical data on the Lower Globigerina Limestone are provided in Table 1 below. Macrofossils within this member include echinoids, molluscs and pteropods. Lower Globigerina Limestone is weathered via solution and salt weathering, primarily through granular disintegration, scaling and alveolar weathering. The Lower Globigerina Limestone member is interpreted to have been deposited in water depths over $200 \mathrm{~m}$ in a depositional environment characterized by free access to the open sea, aerobic conditions, and moderate sedimentation rates (Murray, 1890).
Quarry workers have long recognised the varying aesthetic and weathering characteristics of the Lower Globigerina Limestone. Depending on the quarry area from where the stone is extracted (especially whether it is from the island of Malta or the sister island of Gozo) and depth of extraction (Sammut, 1991), stone "types" have been given different names, associated primarily with appearance but also with some notable changes in physical properties. These include "bajda" (white), "bajda tal-wicc" (surface white), "bajda bit-tebgha tas-sadida" (white with rust stains), "safra" (yellow), "kahla" or "sewda" (blue or black), as well as varying types of "soll" ranging from "soll ahmar" (red "soll") to "soll isfar" (yellow "soll") to "soll ikhal" (blue "soll"). In Malta, the nomenclature is primarily related to typology, whereas in Gozo the nomenclature is strictly sequential. "Gebla tal-franka" ("gebla" meaning "stone") is, however, the generic name for this building stone. Whereas many of the types of "franka" stone are generally reputed to weather well, stone obtained from the various types within the "soll" facies is alleged to be less durable and will deteriorate in a few years, depending on exposure. The two extreme ends of this scale of variations of Lower Globigerina Limestone have been found to differ in geochemical and mineralogical composition, and also in physical properties (Cassar and Vella, 2003; Zammit and Cassar, 2017). The causes of deterioration have been recognised to be the intrinsic properties of the material, as well as environmental causes, including temperature changes, wind, sun, humidity, pollution and the presence of soluble salts (Cassar, 2002).

\section{History of the Use of the Stone}

The Maltese Islands can be characterized both by their strategic location in the central Mediterranean, which has dictated their history of occupation since the Neolithic Era, and their sedimentary geology. The succession of colonisers, who took over the Islands particularly because of their central position, always made good and full use of the readily available and easily quarried soft limestone to build their palaces, temples, forts, as well as magnificent walled cities surrounded by kilometres of fortifications. This activity occurred against a slowly developing backdrop of vernacular building activity which included houses and churches, many of these richly adorned with marvelous and intricate carved decorations. The "franka" or "softstone", is by far the predominant local building and sculptural material, although Coralline Limestone, or "hardstone", another locally occurring stone, has also been widely used on these Islands, but has been somewhat less exploited. The most significant use of the Globigerina Limestone has been on the Maltese Islands, with UNESCO recognising the entire capital city of Valletta, as well as the megalithic prehistoric Temples as World Heritage, mainly built of this limestone; however, over past decades, the stone has also been exported, in not insignificant amounts, to countries such as Italy, Greece and Libya (Mamo, 1936; Ellul, 2010). Ellul (2010) gives a total of about 126,000 tons exported between 1909 and 1938 .

The Maltese Islands have been inhabited for more than six thousand years, with every generation of inhabitants going through more or less intensive periods of building, starting with the prehistoric period which has left behind a rich legacy of magnificent and wellpreserved megalithic monuments, built between the $4^{\text {th }}$ and the $3^{\text {rd }}$ 
Table 1. Description, composition, properties, supply and use of Lower Globigerina Limestone

\begin{tabular}{|c|c|}
\hline Formal Name & Lower Globigerina Limestone \\
\hline $\begin{array}{l}\text { Stratigraphic } \\
\text { (or Geological) Name }\end{array}$ & Lower Globigerina Limestone \\
\hline Commercial Designations & "Franka" "Softstone" \\
\hline Other Names & "Malta stone" \\
\hline Area of Occurrence & Central and southern part of the Island of Malta and northwest of the Island of Gozo (Fig. 2) \\
\hline $\begin{array}{l}\text { Principal Location of } \\
\text { Extraction Sites }\end{array}$ & $\begin{array}{l}\text { Mqabba/Qrendi/Kirkop (active quarries); Siggiewi (active quarries); Naxxar and Birzebbugia (abandoned quar- } \\
\text { ries) - all on the Island of Malta; San Lawrenz (active quarries) on the Island of Gozo In } 2013,66 \text { quarry licenses } \\
\text { were processed; there are also a number of sites that are no longer operating or where operations have been sus- } \\
\text { pended (Fig. 1). }\end{array}$ \\
\hline Production Details (optional) & $\begin{array}{l}\text { Recent research based upon aerial photography taken in } 1994 \text { and } 1998 \text { estimated an annual production of } \\
400,000 \mathrm{~m}^{3} \text { of "softstone" (Entec, 2003). There is, however, a lack of a nationally agreed database on production. }\end{array}$ \\
\hline Manufacturing information & $\begin{array}{l}\text { The processing of the stone starts in the quarry itself and continues on the building site. It is entirely local. } \\
\text { There have been some technological advances in the extraction of this stone over the last decades, but it remains } \\
\text { a basic industry. In the past, the stone was entirely extracted by hand. Nowadays, extraction is made using semi- } \\
\text { automated sawing machines. Other quarry equipment includes facing machines, conveyors and lorries. The } \\
\text { blocks are cut to specific sizes, established by law, and delivered directly to the construction site, where they may } \\
\text { be further finished or carved. (Entec, 2003) }\end{array}$ \\
\hline $\begin{array}{l}\text { Geological Age and } \\
\text { Geological Setting }\end{array}$ & $\begin{array}{l}\text { Sedimentary rock deposited in water depths over } 200 \mathrm{~m} \text { in an environment characterized by free access to the } \\
\text { open sea, aerobic conditions, and moderate sedimentation rates (Pedley et al., 1976). Aquitanian (Early Miocene, } \\
\text { 23.03-20.44 Ma) in age (Felix, 1973; Pedley et al., 1976); Oil Exploration Directorate (1993); (Foresi et al., } \\
\text { 2007; Baldassini et al., 2013) }\end{array}$ \\
\hline $\begin{array}{l}\text { Petrographic Name and } \\
\text { Characteristics }\end{array}$ & $\begin{array}{l}\text { Globigerinid biomicrites, biomicrosparites, wackestones and packstones, pale yellow to cream in colour, medium } \\
\text { to fine grained, massive, bioturbated limestone characterized by a uniform texture (Pedley et al., 1976; Baldassini } \\
\text { and Di Stefano, 2017). }\end{array}$ \\
\hline $\begin{array}{l}\text { Primary Colour(s) and } \\
\text { Aesthetics of Stone }\end{array}$ & $\begin{array}{l}\text { Pale yellow to cream in colour; usually homogeneous; iron oxide stains and bioturbation often occur. } \\
\text { Colour determination by Munsell soil colour charts have given the following ranges: } 10 \mathrm{YR} 6 / 3,10 \mathrm{YR} 8 / 2,10 \mathrm{YR} \\
7 / 6,2.5 \mathrm{Y} 7 / 4,2.5 \mathrm{Y} 8 / 4,2.5 \mathrm{Y} 8 / 2\end{array}$ \\
\hline Technical Properties & 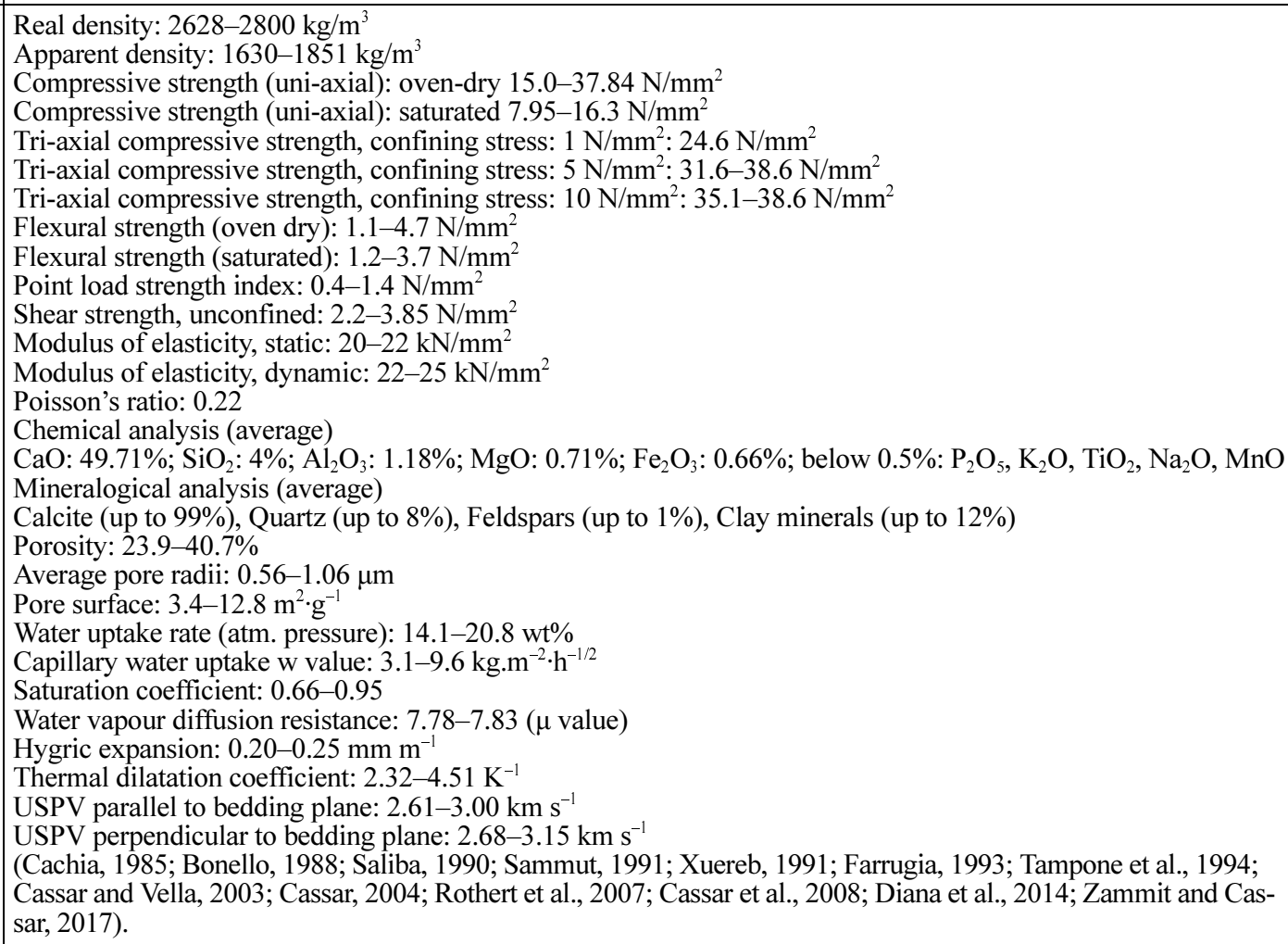 \\
\hline Suitability & $\begin{array}{l}\text { Widely used as a structural material, for building houses, churches (with vaults and domes), public buildings, pal- } \\
\text { aces, schools, hospitals, universities, etc. Also widely used for sculpturing from free-standing objects of all sizes, } \\
\text { to intricately carved in situ stonework. Also flagstones, corbels, roofing slabs, and ornamental work. Used since } \\
\text { the Neolithic period. }\end{array}$ \\
\hline $\begin{array}{l}\text { Vulnerability and Mainte- } \\
\text { nance of Supply }\end{array}$ & $\begin{array}{l}\text { In 1994, the first ever "Mineral Resource Assessment" was carried out for the Maltese Islands. } \\
\text { A final draft report was submitted to the Planning Authority in June } 1996 . \\
\text { Suitable mineral resources were proven in a number of target areas, and for "softstone", the reserves were esti- } \\
\text { mated at } 429 \text { million tonnes (or about } 430 \text { years production) (Entec, 2003). }\end{array}$ \\
\hline
\end{tabular}


Table 1. (continued)

\begin{tabular}{|c|c|}
\hline $\begin{array}{l}\text { Historic Use, Geographic } \\
\text { Area of Utilisation, } \\
\text { Commercial Diffusion }\end{array}$ & $\begin{array}{l}\text { Time span: } 4^{\text {th }} \text { millennium BC to present }-6000 \text { years of continuous use. } \\
\text { Geography: all over the Maltese Islands; exported in the past to areas such as North African countries (including } \\
\text { Libya, Tunisia and Egypt), Greece, including Crete and Corfu, and Turkey, as well as mainland Europe (Belgium, } \\
\text { France, Holland, Italy) and the UK. In all of these cases the amount exported was small, and limited to a few } \\
\text { years, except for export to Greece, Italy and Libya. (Ellul, 2010) } \\
\text { Historical use: Prehistory, Phoenician, Roman and Byzantine, Arab, Late Medieval, Baroque, } 19^{\text {th }} \text { century, Modern }\end{array}$ \\
\hline Buildings etc. & $\begin{array}{l}\text { All of the Maltese Islands' main public institutions are built of the Globigerina Limestone: } \\
\text { - the Presidential Palace (façade begun } 1571) \\
\text { - the Offices of the Prime Minister (Auberge de Castille }-1741-44) \\
\text { - Ministerial Offices (the Auberges of the Knights - late } 16^{\text {th }} \text { century) } \\
\text { - the main hospitals in Malta and Gozo }\left(20^{\text {th }} \text { and } 21^{\text {st }} \text { centuries) }\right. \\
\text { - the current University of Malta and the old University (1960s; } 1592-1609) \\
\text { - historic theatres ( } 1731,1860) \\
\text { - the Bibliotheca and public libraries and archives and schools (late } 18^{\text {th }} \text { century; } 20^{\text {th }} \text { century) } \\
\text { - kilometres of fortifications, forts and watchtowers }\left(16^{\text {th }}-17^{\text {th }} \text { century) }\right. \\
\text { - Natl monasteries, main cathedrals and churches, as well as smaller chapels including rural ones (Medieval to } 20^{\text {th }} \text { century) } \\
\text { - and vernacular architecture (Medieval to } 21^{\text {st }} \text { century) }\end{array}$ \\
\hline Related Heritage Issues & $\begin{array}{l}\text { Cultural relevance: Prehistoric Temples, and city of Valletta, Malta's capital city are UNESCO World Heritage } \\
\text { sites. Others, such as the walled city of Mdina, the Cittadella (Gozo), and the Knights' Grand Harbour area forti- } \\
\text { fications have been formally submitted, and are currently on the UNESCO Tentative List. (http://whc.unesco.org/ } \\
\text { en/statesparties/MT/) }\end{array}$ \\
\hline Related Dimension Stones & Coralline Limestone \\
\hline $\begin{array}{l}\text { Principal Literature related to } \\
\text { the Designated Stone }\end{array}$ & See list of References \\
\hline
\end{tabular}

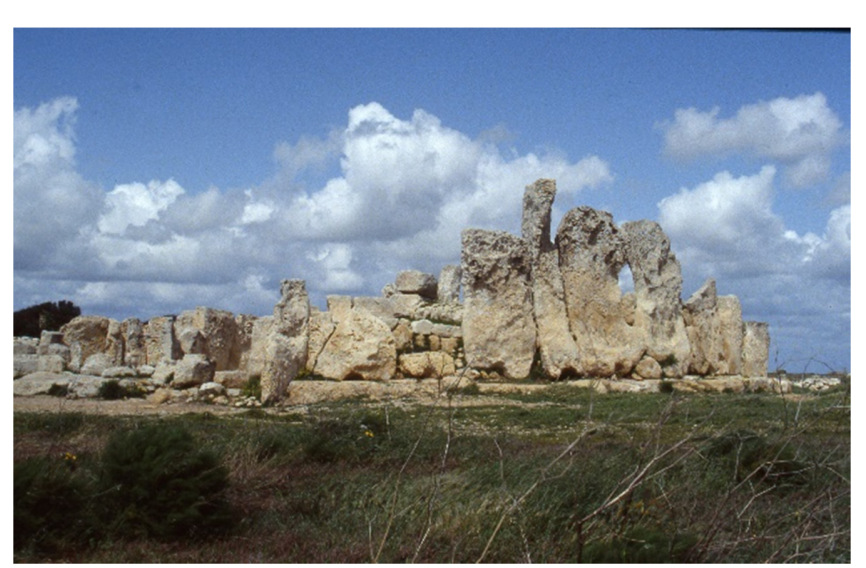

Figure 6. The Prehistoric Temples of Malta $\left(4^{\text {th }}-3^{\text {rd }}\right.$ millennium $B C$ ), included on the UNESCO World Heritage List, are amongst the earliest free-standing stone structures in the world. Hagar Qim, shown in this figure, as well as the Temples of Mnajdra and Tarxien, are now sheltered for their conservation.

millennium BC (Fig. 6). These are considered to be amongst the oldest freestanding buildings in the world, and are inscribed on the UNESCO World Heritage List as some of the earliest still extant limestone structures in the world, listed "because of their originality, complexity and striking massive proportions, but also because of the considerable technical skill required in their construction" (http://whc.unesco. org/en/list/132). Other remains from later periods, scattered all over the Islands, include Bronze Age defended settlements, Phoenician sanctuaries and rock-cut tombs, Roman villas, estates and baths in the countryside and by the sea, late Roman and Byzantine Catacombs, and Islamic burial grounds. All are built with this local material, important to the present day (http://www.culturalheritage.gov.mt/).

The first recorded mention of the limestone of the Maltese Islands
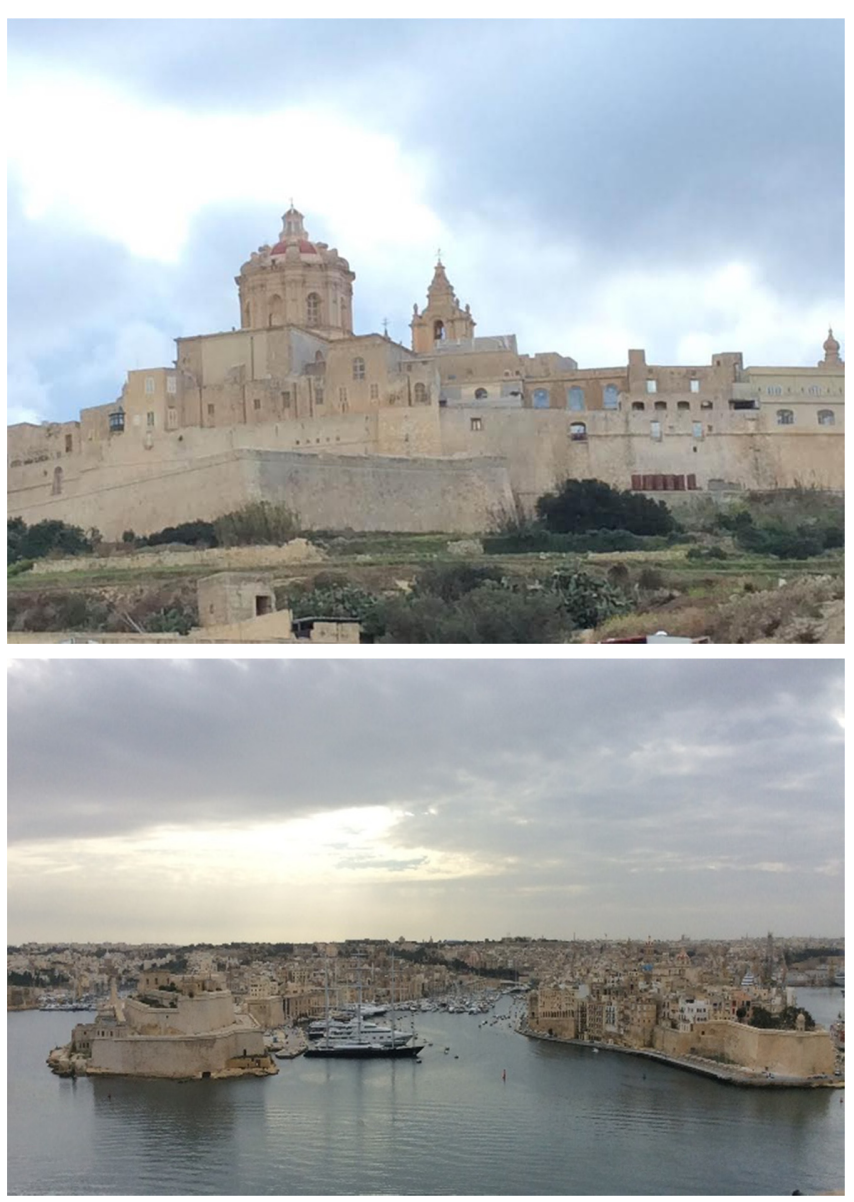

Figures 7 (upper) and 8 (lower). The fortifications of the cities of Mdina (late $17^{\text {th }}$ to early $18^{\text {th }}$ century) and Valletta (late $16^{\text {th }}$ century) (shown here), and those of Vittoriosa and the Citadel (Gozo) (not shown here) comprise over $60 \mathrm{~km}$ of massively built Globigerina Limestone bastions, enceintes, ramparts and watch towers. 

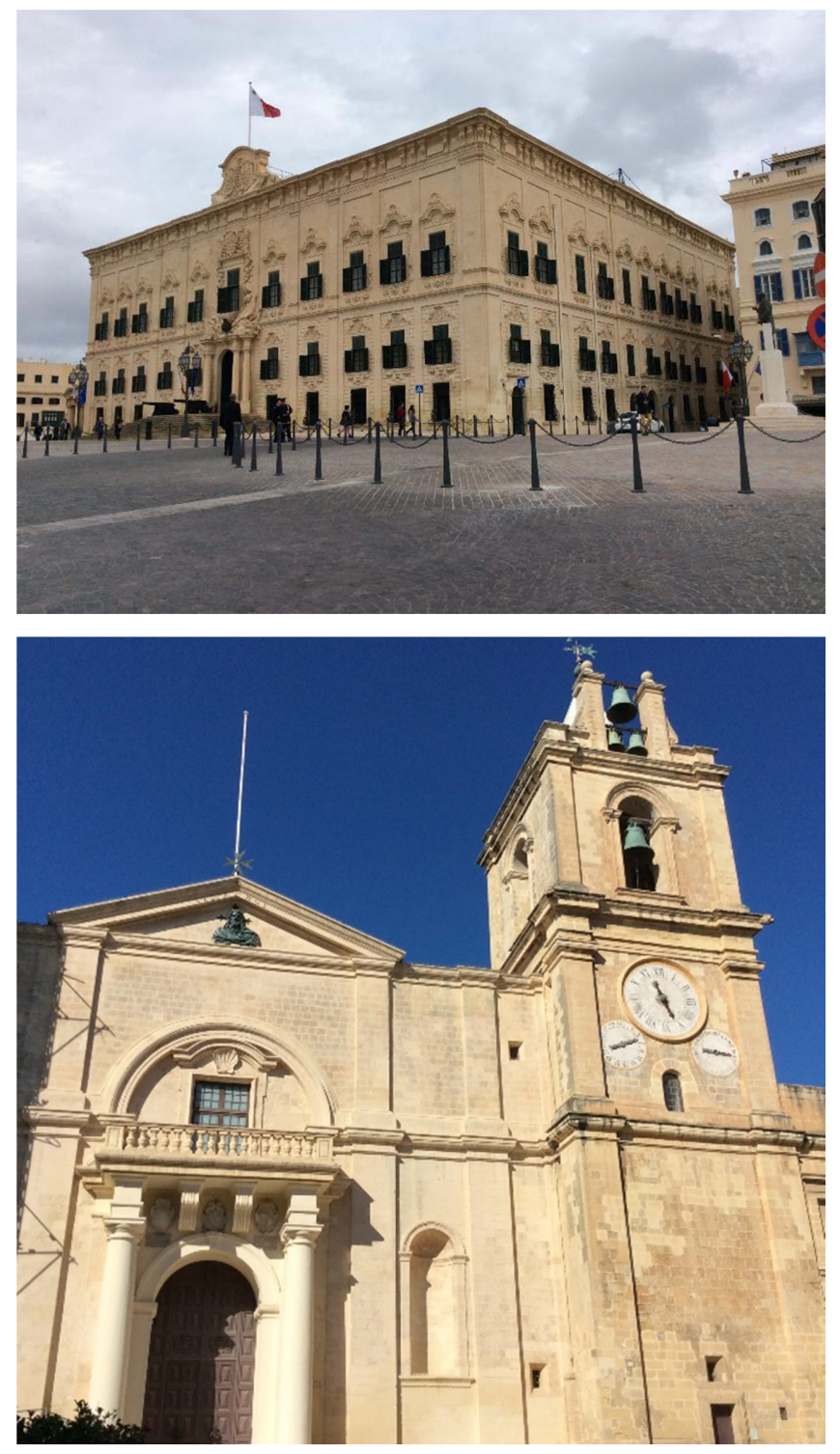

Figures 9 (upper) and (lower) 10. Two of the most prominent buildings in the UNESCO city of Valletta, Auberge de Castille (the current Offices of the Prime Minister) (1741-44) and the Co-Cathedral of St. John, the Conventual Church of the Knights (1573-77). Other prominent buildings in the City include the Presidential Palace (formerly the palace of the Grand Master of the Knights of St John) (began in 1571) and the Bibliotheca (National Library) (1786-96) which houses the archives of the Order of St. John.

was in The Earliest Description of Malta published in Lyons in 1536 by Jean Quintin d'Autin (Vella, 1980, pp. 37-39) who mentions the "white" stone which is "remarkable for its softness; it is sawed more easily than wood." The mode of excavation is also mentioned: "Often huge blocks of stones are prised loose by wedges from the solid rock. Hence it is worked easily..." Another Descrittione di Malta, this time dating to 1716 , mentions that the houses are made of white stone, which is very easy to cut (Mallia-Milanes, 1988, p. 51).

But by far the greatest and best use of the stone prior to modern

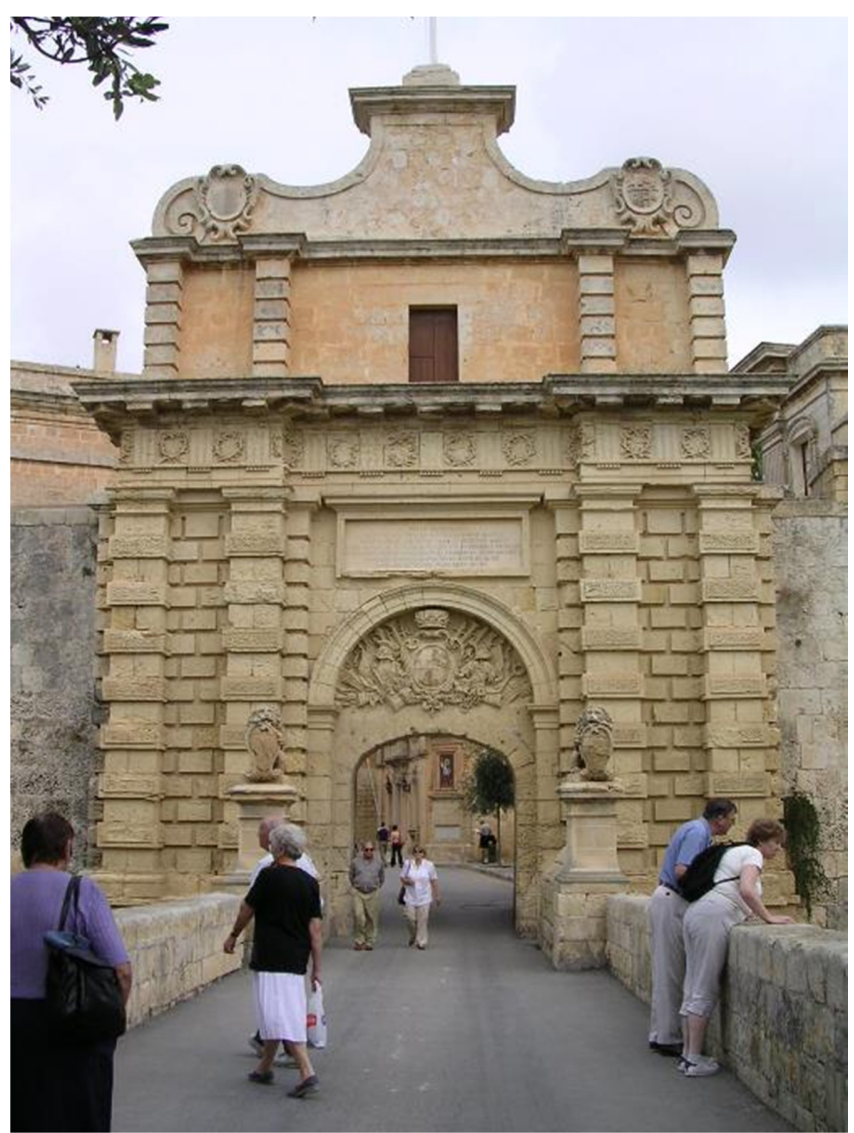

Figure 11. One of the decorative portals of the old capital of Mdina, the Main Gate (1724).

times was made during the Renaissance and Baroque periods, under the Knights of St John. These include numerous systems of fortifications (over 60 kilometres in length) which, following extensive recent restoration efforts, still glorify the Maltese urban landscape (Figs. 7 and 8). Malta's rich Renaissance and Baroque architectural heritage extends beyond the UNESCO recognised capital city, Valletta (whc.unesco. org/en/list/131), built by the Knights after the Great Siege of 1565 (Figs. 9 and 10). The fortified city of Mdina (Fig. 11), the old capital of Malta, still stands as proud testimony to the great $18^{\text {th }}$ century architect François de Mondion, who was the resident engineer of the Knights of St John from 1715 to 1733 (Mahoney, 1996, p 208). Other imposing constructions in this stone include the fortified Three Cities of the Grand Harbour area, as well as numerous villages spread all over the Maltese archipelago, characterized by magnificent and elaborate Baroque churches (Fig. 12) that dominate the Maltese skyline (http://www.culturalheritage.gov.mt/). Vernacular architecture in this honey-coloured stone also characterizes the Maltese landscape (Fig. 13).

In 1800, when the Maltese Islands passed under British Colonial Rule, architectural styles and building techniques changed slowly; however the main construction material remained the local Lower Globigerina Limestone. When construction did take place, especially in the early period, it was primarily in the form of military buildings, and monuments to naval and army officers; residential barracks and forts and fortifications were also built (Spiteri, 1991). The preferred 


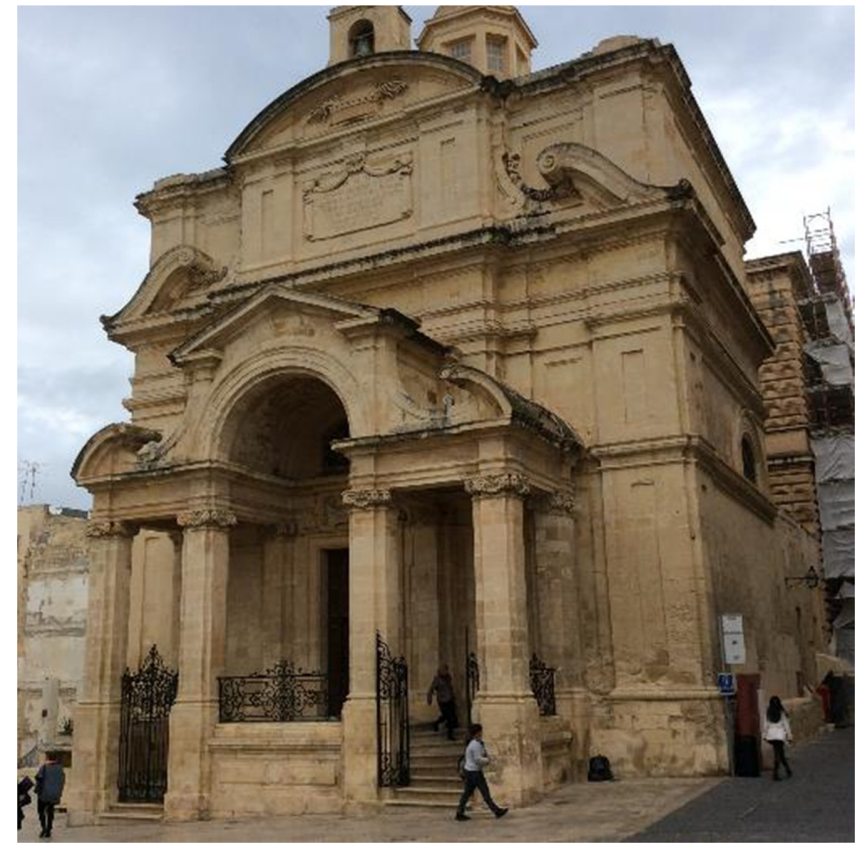

Figure 12. The elaborate façade of one of Malta's most prestigious limestone Baroque Churches: the Church of St. Caterina d'Italia (Valletta) (1713).

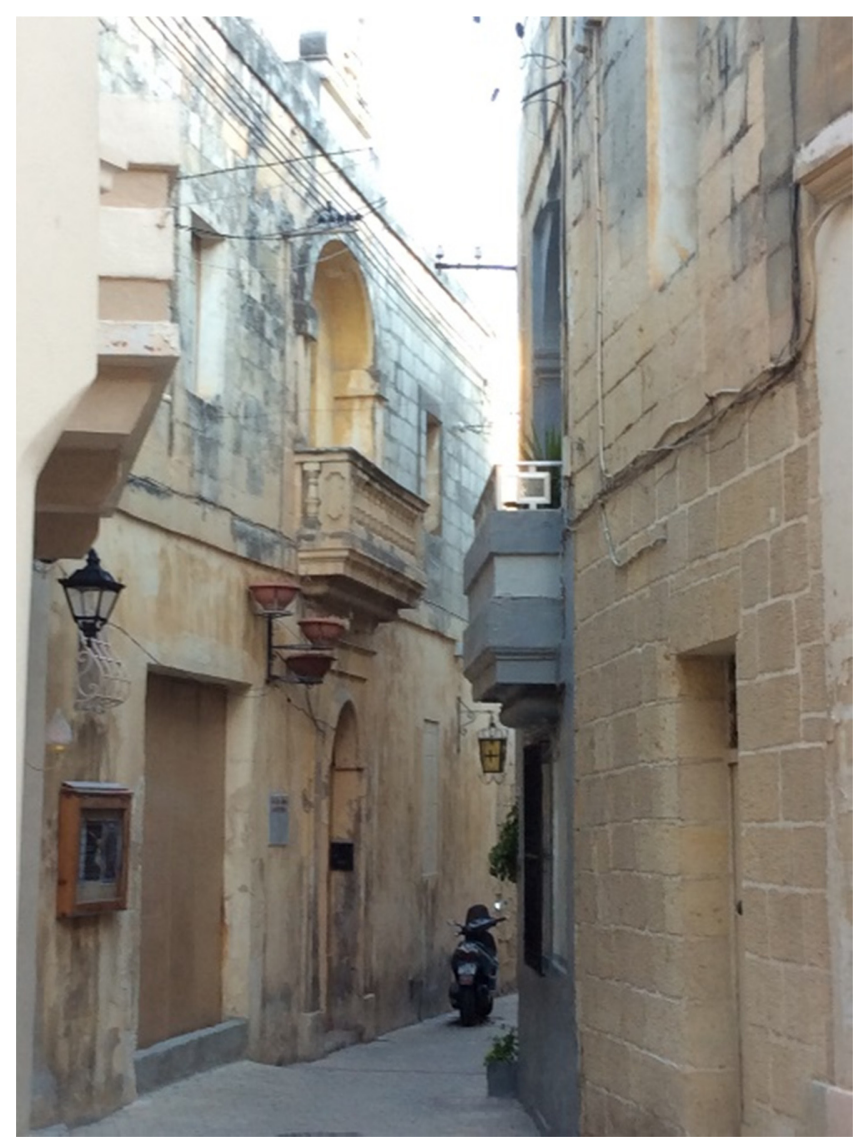

Figure 13. Typical and traditional village streetscape, with traditional limestone houses and decorative stone balconies.

style for British constructions was the Neo-Classic Revival "to assert their presence on the Islands and as a symbol of their Imperial might

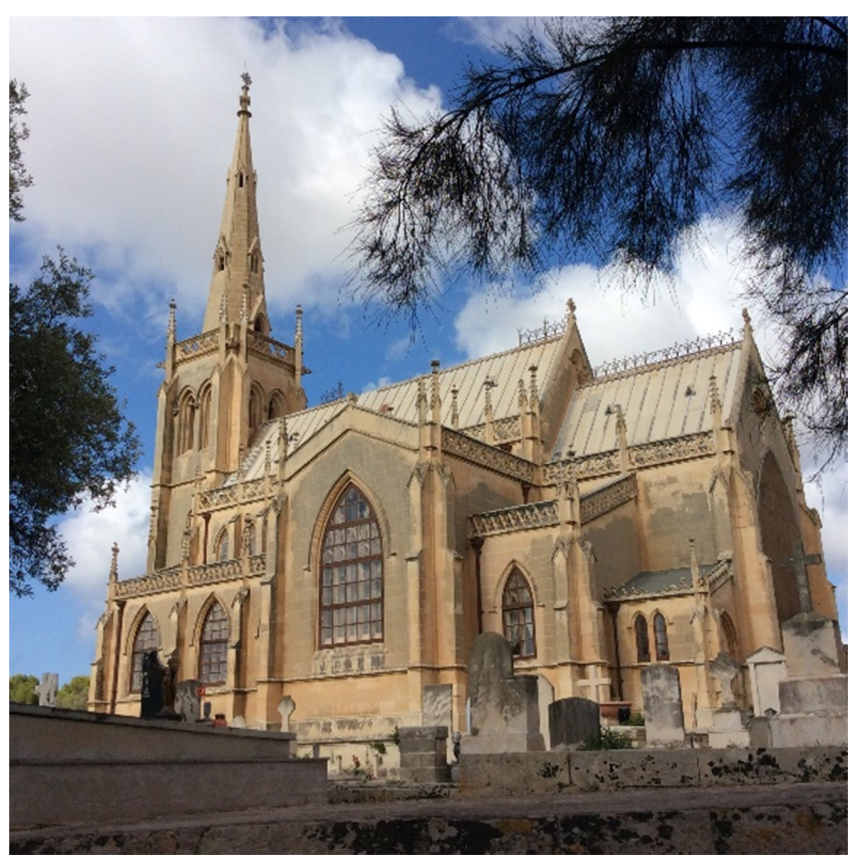

Figure 14. The $19^{\text {th }}$ century Neo-Gothic church at the Addolorata Cemetery, Malta.

and glory" (Mahoney, 1996, p. 211). Local architects, such a the renowned Emanuele Luigi Galizia also left his mark during this period (Fig. 14).

At the beginning of the twentieth century, new aesthetic ideas were introduced, with the Romanesque, the Neo-Gothic, and the Art Nouveau movements being the main ones. In the last two decades, more innovative, hybrid styles were introduced, influenced by an increased appreciation of the Islands' architectural heritage and current trends in Europe (http://www.victorborg.com/). All continued to make extensive use of the local limestone.

The soft Maltese limestone has also been extensively used for sculpture, from very simple forms to elaborate representations, even from prehistoric times. The megalithic Temples bear elaborate spiral carvings (Fig. 15), as well as animal reliefs and stone statues and statuettes. The Romans used the stone to carve busts and heads, as well as

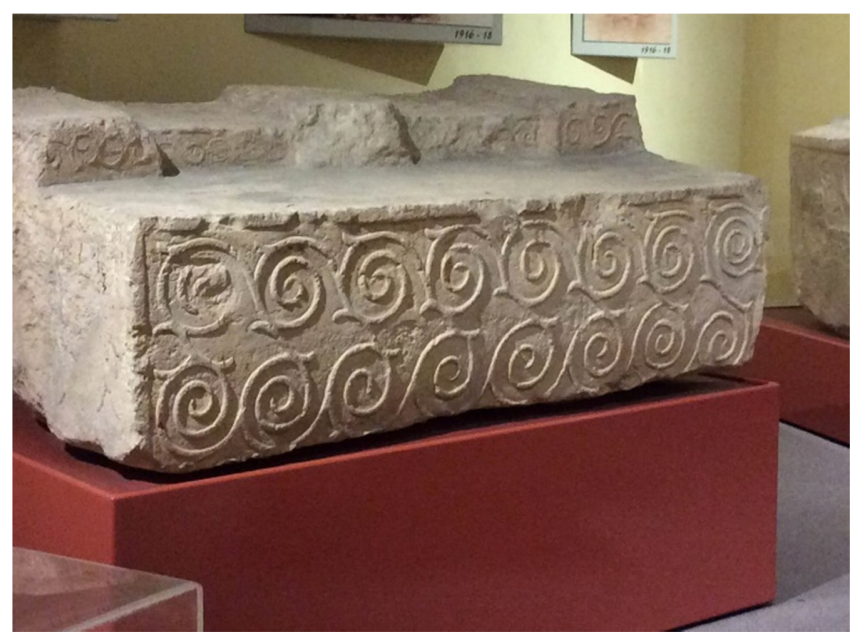

Figure 15. Prehistoric limestone relief, dating to the Neolithic, carved out of the soft limestone with stone (obsidian and chert) tools. 


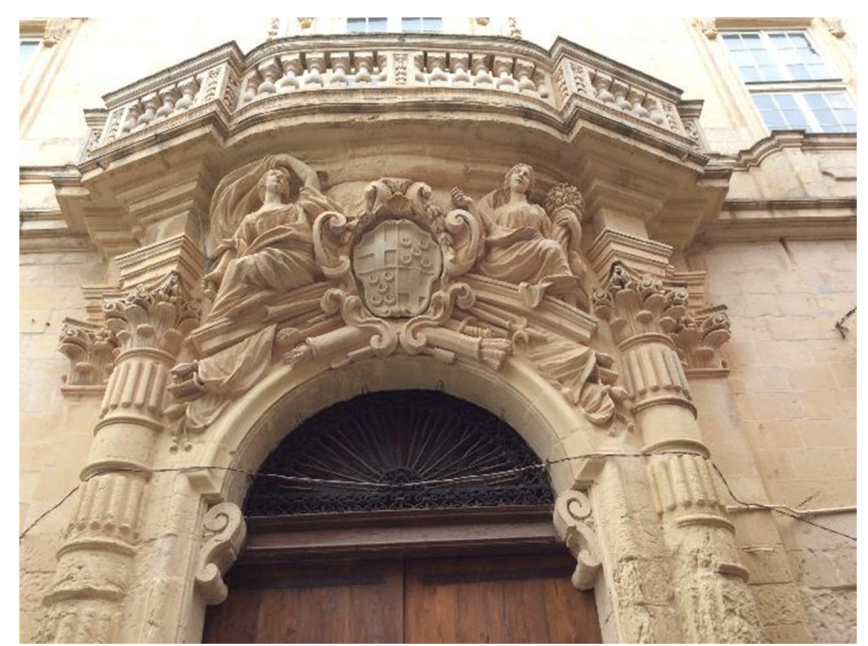

Figure 16. The easily carved Lower Globigerina Limestone effortlessly lent itself to elaborate and profuse Baroque sculpture. An extravagant doorway in the old city of Rabat (Malta).

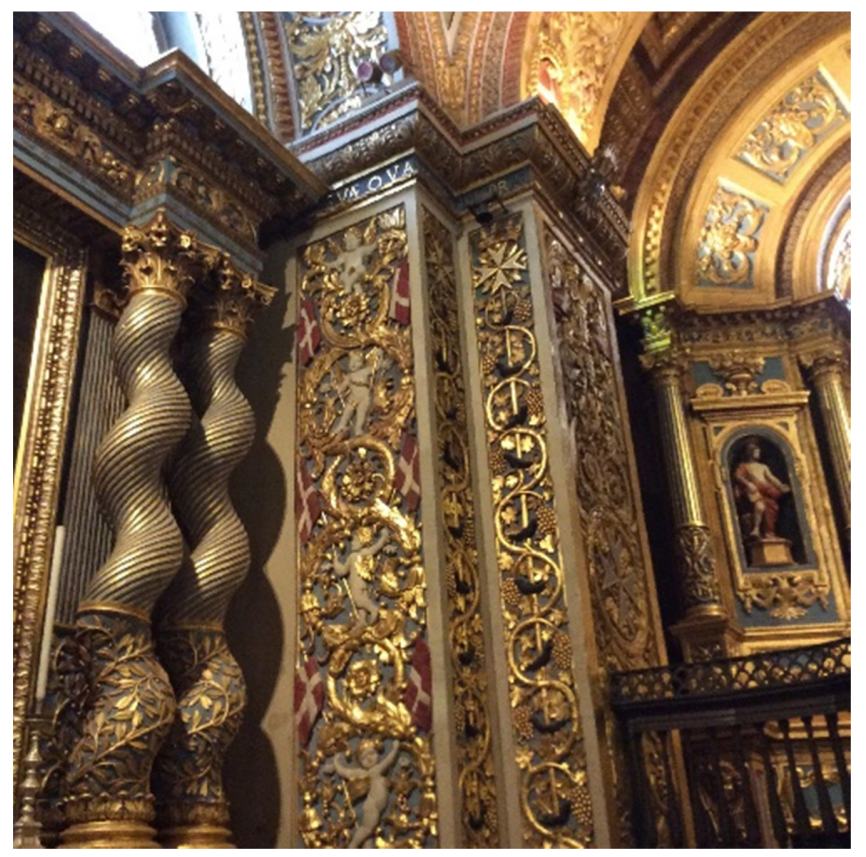

Figure 17. The magnificent carved and gilt interior (all of carved Globigerina Limestone) of St. John's Co-Cathedral in Valletta, the Conventual Church of the Knights of St. John. Many of the Baroque buildings built by the Knights had correspondingly meticulously carved interiors.

great fluted columns and capitals to decorate their buildings. However, the pinnacle of stone carving in Malta was achieved during the Baroque Period (Fig. 16), as exemplified by the inside of St John's Co-Cathedral in Valletta (1577), when extremely elaborate decorations were carved, with the same ease as carving wood (Fig. 17).

\section{The Stone as an Economic Resource}

There are currently around 100 licensed "softstone" and "hardstone" quarries in Malta and Gozo (Fig. 3). In 2013, the Malta Resource Authority processed 34 new licenses to operate "softstone" quarries, and 32 renewals (MRA, 2013). The "softstone" industry is operated by a work force of approximately 500 persons (Lino Bianco and Associates, 2000), mostly part-timers or family members. The gross annual production for this stone has been given to be in the region of 860,000 $\mathrm{m}^{3}$. It has, however, also been estimated that $45 \%$ of "lesser quality" quarried material is discarded annually. The reserves of "softstone" and "hardstone" in existing local quarries, or where quarrying is permitted have been arguably estimated to last fewer than 40 years (Times of Malta, 2003).

There is, however, a lack of a nationally agreed database on production, with data output generally being incomplete. Research based upon aerial photography taken in 1994 and 1998 estimated an annual production of 400,000 $\mathrm{m}^{3}$ of "softstone" (Entec, 2003). Data on the amount of quarry stone which is used annually for the maintenance and restoration of historic buildings is not available; however it is important to note that it is also the continued use of this stone in new buildings that keeps the quarries active and a relevant part of the local economy.

In 1994, the first ever "Mineral Resource Assessment" was carried out for the Maltese Islands. A final draft report was submitted to the Planning Authority in June 1996. Suitable mineral resources were proven in a number of target areas, many not currently quarried, and for "softstone", the reserves were estimated at 429 million tonnes (or about 430 years production at the current rate of extraction) (Entec, 2003).

In construction, the whiter resources, with a consistent colouring, tend to be preferred by consumers. Minor variations in colour can result in the stone being discarded. Decisions on material quality are still made at the quarry face, on the basis of visual assessment, with significant resulting wastage (Entec, 2003). Today, "softstone" quarrying is going through a lull, with the stone becoming less popular for everyday constructions, and with much fewer quarries being active, also as a result of the decline of both the manpower as well as the skills required for stone masonry. The present active ones are primarily located in two areas in Malta (Mqabba and Siggiewi), and in one area in Gozo (Dwejra) (Fig. 1).

\section{GHSR Nomination/Citation Requirements}

Following the 2014 checklist, outlining the data required in order to nominate a natural stone as a GHSR, Table 1 gives the information requested.

\section{Conclusion}

The Globigerina Limestone Formation is described as a yellow to greyish, medium to fine grained wackestone-packstone which is massive, poorly to moderately consolidated, and intensely burrowed. Deposited in outer shelf environments between the Late Chattian and Langhian, it is up to $200 \mathrm{~m}$ thick. It is made up of three members, of which it is the Lower Globigerina Limestone which has been used as the main local building material in continuous use for 6000 years. It 
comprises planktonic foraminiferal biomicrites, biomicrosparites, wackestones and packstones dominated by globigerinid tests. Most of the original bedding of the member has been destroyed by intense bioturbation.

All buildings and sites of importance in the Maltese Islands are built using this stone, including those designated as UNESCO World Heritage sites. There has also been a degree of exportation of the material in the past, with buildings such as the Royal Palace in Athens, St Louis Cathedral in Carthage and a Protestant Church in Naples being built of this stone. The cultural and historical significance of this limestone is thus indisputable. Although the durability of this material is variable, and some facies are known to deteriorate badly in the marine environment in which they are located, other strata are of exceptional durability, with hundreds, or even thousands of years not having a deleterious effect on the materials. Quarrying continues to the present, the stone being the only natural resource of any importance to be found on the Islands. The material is still an important pillar of the Maltese economy. A Resource Assessment (in 1994) estimated that the Globigerina Limestone resources can last another 450 years. This however would involve opening up new areas, something which is not currently being considered. The permitted reserves of "softstone" and "hardstone" in existing local quarries are however estimated to last about 40 years.

\section{References}

Baldassini, N., and Di Stefano, A., 2017, Stratigraphic features of the Maltese Archipelago: a synthesis: Natural Hazards, v. 86, no. 2, pp. 203231.

Baldassini, N., Mazzei, R., Foresi, L.M., Riforgiato, F., and Salvatorini, G., 2013, Calcareous plankton bio-chronostratigraphy of the Maltese Lower Globigerina Limestone member: Acta Geologica Polonica, v. 63, no. 1, pp. 105-135.

Bianchi, P., 1975, Building in Stone: A.\&C.E. Dissertation (unpublished), University of Malta, Msida.

Bonanno, A., 2005, Malta Phoenician, Punic, and Roman: Midsea Books, Sta Venera, $359 \mathrm{p}$.

Bonello, S., 1988, Engineering Properties of Rocks and Soils of the Maltese Island: B.E.\&A. Dissertation (unpublished), University of Malta, Msida.

Borg, V., http://www.victorborg.com/ (Accessed in April 2016).

Buhagiar, K., and Cassar, J., 2003, Fort Chambray: The genesis and realisation of a project in eighteenth century Malta: Melita Historica, v. 13, no. 4, pp. 347-364.

Buhagiar, M., 2005, The Late Medieval Art and Architecture of the Maltese Islands: Fondazzjoni Patrimonju Malti, Valletta, 278 p.

Building Research Station, 1958, The Maltese Islands: Use of Limestone for Building (unpublished): Department of Scientific and Industrial Research, BRS, Watford, UK.

Building Research Station, 1963, Maltese Limestones: Relation of Durability to Laboratory-measured Properties and Efficacy of Silicone Treatments: Note no. C965 (unpublished). Department of Scientific and Industrial Research, BRS, Watford, UK.

Building Research Station, 1964, The Maltese Islands: Properties and Behaviour of Local Limestone: Internal note 6 (unpublished). Department of Scientific and Industrial Research, BRS, Watford, UK.

Cachia, J., 1985, The Mechanical and Physical Properties of the Globigerina Limestone as used in Local Masonry Construction: A.\&C.E. Dissertation (unpublished), University of Malta, Msida.

Cassar, J., 2002, Deterioration of the Globigerina Limestone of the Maltese Islands. in Siegesmund, S., Weiss, T., and Vollbrecht, A. (eds.), Natural
Stone, Weathering Phenomena, Conservation Strategies and Case Studies: Geological Society of London, Special Publications, 205, pp. 33-49.

Cassar, J., 2004, Composition and property data of Malta's building stone for the construction of a database. in Přikryl, R., and Siegl, P. (eds.), Architectural and Sculptural Stone in Cultural Landscape: Karolinium Press, Prague, pp. 11-28.

Cassar, J., 2010, The use of limestone in a historic context - the experience of Malta. in Smith, B.J., Gomez-Heras, M., Viles, H.A., and Cassar, J. (eds.), Limestone in the Built Environment: Present-day Challenges for the Preservation of the Past: Geological Society of London, Special Publications, 331, pp. 13-25.

Cassar, J., and Vannucci, S., 2001, Petrographical and chemical research on the stone of the Megalithic Temples: Malta Archaeological Review, Issue 5, pp. 40-45.

Cassar, J., and Vella, A.J., 2003, Methodology to identify badly weathering limestone using geochemistry: Case study of the Lower Globigerina Limestone of the Maltese Islands: Quarterly Journal of Engineering Geology and Hydrogeology, v. 36, pp. 85-96.

Cassar, J., Marrocchi, A., Santarelli, M.L., and Muscat, M., 2008, Controlling crystallization damage by the use of salt inhibitors on Malta's limestone: Materiales de construcción, v. 58, no. 289-290, pp. 281-293.

Cilia, D. (ed.), 2004, Malta before History: Miranda Publishers, Sliema, $440 \mathrm{p}$.

Cooper, B., 2014, The 'Global Heritage Stone Resource' designation: past, present and future: The Geological Society of London, Special Publication, 407, pp. 11-20.

Diana, G., Cassar, J., and Zammit, G., 2014, Physical characteristics of Globigerina Limestone using ultrasonic and thermographic methods: Quarterly Journal of Engineering Geology and Hydrogeology, v. 47, no. 3, pp. 251-257.

De Giorgio, R., 1985, A City by an Order ( $2^{\text {nd }}$ edition): Progress Press Co. Ltd., Valletta, $259 \mathrm{p}$.

Ellul, M., 2010, Malta limestone goes to Europe: Use of Malta stone outside Malta: The Malta Historical Society. http://mhs.eu.pn/60/60 25.html

ENTEC and Planning Authority, Malta, 2003, Minerals Subject Plan for the Maltese Islands 2002: Final Report and Annexes, May 2003, Entec UK Limited.

Farrugia, P., 1993, Porosity and Related Properties of Local Building Stone: B.E.\&A. Dissertation (unpublished), University of Malta, Msida.

Felix, R., 1973, Oligo-Miocene stratigraphy of Malta and Gozo: Doctoral Thesis, Utrecht University, Utrecht, 103 p.

Fiorini, S., 1993, Malta in 1530. in Mallia-Milanes, V. (ed.), Hospitaller Malta 1530-1798: Mireva Publications, Msida, pp. 111-198.

Fitzner, B., Heinrichs, K., and Volker, M., 1996, Model for salt weathering at Maltese Globigerina Limestones: EC Research Workshop on Origin, Mechanisms and Effects of Salts on Degradation of Monuments in Marine and Continental Environments, Bari, Italy, 1996, pp. 331-344.

Foresi, L.M., Mazzei, R., Salvatorini, G., and Donia, F., 2007, Biostratigraphy and chronostratigraphy of the Maltese Lower Globigerina Limestone Member (Globigerina Limestone Formation): New preliminary data based on calcareous plankton: Bollettino della Società Paleontologica Italiana, v. 46 , no. $2-3$, pp. $175-181$.

Global Heritage Stone website, www.globalheritagestone.com (Accessed April 2016).

Grima, R., 2004, The landscape context of megalithic architecture. in Cilia, D. (ed.), Malta before History: Miranda, Sliema, pp. 327-345.

Hughes, Q., 1993, The architectural development of Hospitaller Malta. in Mallia-Milanes, V. (ed.), Hospitaller Malta 1530-1798: Mireva Publications, Msida, pp. 483-507.

Hughes, T., Lott, G.K., Poultney, M.J., and Cooper, B.J., 2013, Portland stone: A nomination for "Global Heritage Stone Resource" from the United Kingdom: Episodes, v. 36, no. 3, pp. 221-226.

Hyde, H.P.T., 1955, Geology of the Maltese Islands: Lux Press, Valletta, $135 \mathrm{p}$.

Lino Bianco and Associates, 2000, Retention of the status quo regarding 
the exportation of Maltese Stone: Study for the Ministry for Economic Services, Malta. http://www.lino-bianco.com/otherprojects/images/ 3 exportation/retentionofthestatusquo.pdf (Accessed April 2016).

Luttrell, A.T., 1976, Hal Millieri: A Maltese Casale, Its Churches and Paintings: Midsea Books, Sta Venera, 143 p.

Mahoney, L., 1996, 5000 Years of Architecture in Malta. Valletta Publishing, Valletta, $399 \mathrm{p}$.

Mallia-Milanes, V. (ed.), 1988, Descrittione di Malta Anno 1716: A Venetian Account: Bugelli Publications, Valletta, $119 \mathrm{p}$.

Mamo, J., 1936, Marbles and limestones of Malta: Sands, Clays and Minerals, v. 2, no. 4, pp. 83-88

Marker, B.R., 2014, Bath stone and Purbeck stone: A comparison in terms of criteria for Global Heritage Stone Resource designation: Episodes, v. 38, no. 2, pp. 118-123.

MRA (Malta Resources Authority), 2013, Annual Report: http://mra. org.mt/wp-content/uploads/2012/08/1397/ANNUAL-REPORT-2013WEB.pdf (Accessed March 2016).

Murray, J., 1890, The Maltese Islands with special reference to their geological structure: Scottish Geographical Magazine, v. 6, pp. 449-488.

Oil Exploration Directorate, 1993, Geological Map of the Maltese Islands. Office of the Prime Minister, Malta.

Pace, A. (ed.), 1996, Maltese Prehistoric Art 5000-2500 BC: Fondazzjoni Patrimonju Malti, Valletta, $88 \mathrm{p}$.

Pedley, H.M., 1978, A new lithostratigraphical and paleoenvironmental interpretation for the coralline limestone formations (Miocene) of the Maltese Islands: Institute of Geological Sciences for Overseas Geological Mineral Resources, v. 54, pp. 273-291.

Pedley, H.M., and Hughes Clarke, M., 2002, Geological Itineraries in Malta and Gozo: Publishers Enterprises Group, San Gwann, 64 p.

Pedley, H.M., House, M.R., and Waugh, B., 1976, The geology of Malta and Gozo: Proceedings of the Geologists' Association 87, pp. 325-341.

Pedley, H.M., and Hughes Clarke, M., 2002, Limestone Isles in a Crystal Sea: Publishers Enterprises Group, San Gwann, 109 p.

Rothert, E., Eggers, T., Cassar, J., Ruedrich, J., Fitzner B., and Siegesmund, S., 2007, Stone properties and weathering induced by salt crystallization of Maltese Globigerina Limestone: Geological Society of London, Special Publications, 271, pp. 189-198.

Saliba, J., 1990, The Shear Strength of the Globigerina Limestone: B.E. \&A. Dissertation (unpublished), University of Malta, Msida.

Sammut, A., 1991, An Assessment of Globigerina Limestone Resources: B.E.\&A. Dissertation (unpublished), University of Malta, Msida.

Spiteri, S.C., 1991, The British Fortifications: An Illustrated Guide to the British Fortifications in Malta: Stephen C. Spiteri, Valletta, 243 p.

Spiteri, S.C., 2008, The Art of Fortress Building in Hospitaller Malta: BDL Publishing, San Gwann.

Superintendence of Cultural Heritage (Malta), http://www.culturalheritage.gov.mt/ (Accessed April 2016).

Tampone, G, Vannucci, S., and Cassar, J., 1987, Nuove Ipotesi sull'Architettura del Tempio Megalitico di Ggantija a Gozo [New hypotheses on the architecture of the Megalithic Temple of Ggantija in Gozo]: Bollettino Ingegnieri, v. 3, pp. 3-21.

Tampone, G., Vannucci, S., Cassar, J., and Giordano, S., 1994, I Templi Megalitici Preistorici delle Isole Maltesi: Determinazione delle Propieta' Meccaniche dei Materiali ed Interpretazione dei Dissesti [Prehistoric Megalithic Temples of the Maltese Archipelago: determination of mechanical properties of materials and interpretation of structural failures]: Proceedings of the $3^{\text {rd }}$ International Symposium on Conservation of Monuments in the Mediterranean Basin, Venice, pp. 567-575.

Times of Malta, 2003, MEPA makes a point: http://www.timesofmalta.com/ articles/view/20030425/opinion/mepa-makes-a-point.151518 (Accessed April 2016).

Torpiano, A., 2004, The construction of the prehistoric megalithic temples of Malta. in Cilia, D. (ed.), Malta before History: Miranda Publishers, Sliema.

Trump, D.H., 2002, Malta: Prehistory and Temples ( $3^{\text {rd }}$ edition): Midsea
Books, Sta Venera, $319 \mathrm{p}$.

UNESCO, City of Valletta: http://whc.unesco.org/en/list/131 (Accessed April 2016).

UNESCO, Malta: http://whc.unesco.org/en/statesparties/MT/ (Accessed April 2016)

UNESCO, Megalithic Temples of Malta: http://whc.unesco.org/en/list/132 (Accessed April 2016).

Vella, H.C.R., 1980, The Earliest Description of Malta (Lyons 1536): Translation of Jean Quintin d'Autin Insulae Melitae Descriptio, DeBono Enterprises, Sliema.

Xuereb, D., 1991, Elastic Constants of Globigerina Limestone: B.E.\&A. Dissertation (unpublished), University of Malta, Msida.

Zammit, G., 1989, Performance Testing of Locally Available, Transparent Protective-coatings on Globigerina Limestone: B.E.\&A. Dissertation (unpublished), University of Malta, Msida.

Zammit, T., and Cassar, J., 2017, Investigating possible correlations between the porosimetry and insoluble residue content of Malta's Lower Globigerina Limestone: Bulletin of Engineering Geology and the Environment, v. 76, no. 1, pp. 59-70.

Zammit, V., 2004, The Limestone Heritage: Siggiewi: Heritage Books, Sta Venera, $28 \mathrm{p}$.

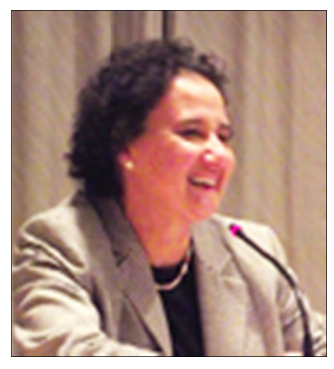

JoAnn Cassar is a Full Professor at the University of Malta, and Head of the Department of Conservation and Built Heritage. She has carried out research for over 30 years on the local limestone, has over sixty scientific publications and is the co-editor of five books. She is a member of the Board of Directors of Heritage Malta and sits on the Scientific Committee for the Conservation of the UNESCO-listed Megalithic Temples of Malta. Prof. Cassar is a Fellow of the International Institute for Conservation (FIIC), Fellow of the Geological Society (FGS), Chartered Chemist and Fellow of the Royal Society of Chemistry (CChem FRSC).

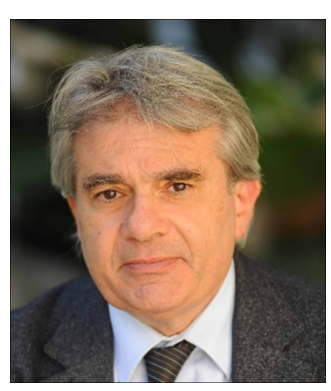

Prof. Alex Torpiano is an Architect and Structural Engineer, currently Dean of the Faculty for the Built Environment. He has had a long career in private practice, and set up what is now a leading architectural and structural engineering practice in Malta; he has also led a multi-disciplinary practice. $\mathrm{He}$ has worked on many projects involving the restoration of heritage masonry structures, including forts, palaces and local parish churches, and also on the Prehistoric Temples of Malta. At the University of Malta, he has also acted as Chairman of the International Institute of Baroque Studies. He has been Chairman of the Valletta Rehabilitation Committee, and also President of the Council of the Chamber of Architects and Civil Engineers. 


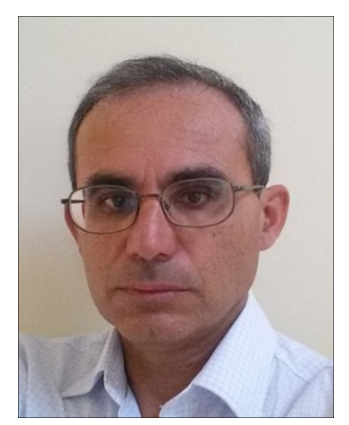

Tano Zammit B.E. \& A (Hons.) is a warranted architect and civil engineer with twentyseven years' experience, mainly as a project manager, in the building construction industry. He graduated from the University of Malta in 1989 and has recently concluded his Ph.D., wherein he conducted empirical investigations on the durability of Globigerina Limestone. At present he is a member of the Management Committee for the Mdina Cathedral and a project coordinator for several ecclesial conservation projects. He is also a part-time lecturer on traditional building materials and porosimetry at the Department of Conservation and Built Heritage, University of Malta.

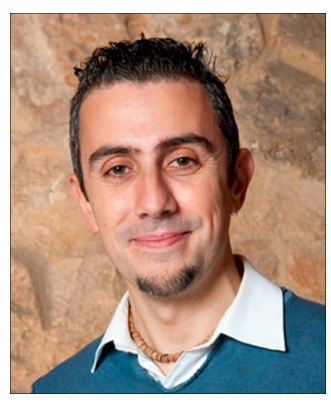

Aaron Micallef is a Senior Lecturer and Marie Curie fellow at the Department of Geosciences, University of Malta. As a marine geologist he analyses geophysical and sedimentological data to solve problems related to submarine landslides, canyons, carbonate escarpments, hydrogeology and seafloor mapping. His areas of study include the Mediterranean Sea, Atlantic and Pacific oceans. Aaron graduated from the University of Oxford with a Masters degree in geomorphology, where he worked on the weathering of sandstones and limestones. $\mathrm{He}$ completed his $\mathrm{PhD}$ in marine geology at the National Oceanography Centre, Southampton. 